\title{
PENGEMBANGAN LEMBAR KERJA PESERTA DIDIK (LKPD) IPA BERORIENTASI TRI HITA KARANA PADA KELAS V SEKOLAH DASAR
}

\author{
P.G.A. Dikta ${ }^{1}$, I.W. Lasmawan ${ }^{2}$, I.B.P. Arnyana ${ }^{3}$ \\ ${ }^{123}$ Program Studi Pendidikan Dasar \\ Universitas Pendidikan Ganesha \\ Denpasar, Indonesia
e-mail: pg.asnawa@gmail.com ${ }^{1}$, wayan.lasmawan@undiksha.ac.id ${ }^{2}$, putu.arnyana@undiksha.ac.id ${ }^{3}$

\begin{abstract}
Abstrak
Penelitian ini memiliki tujuan untuk mendapatkan: 1) lembar kerja peserta didik IPA berorientasi Tri Hita Karana yang valid; 2) lembar kerja peserta didik IPA berorientasi Tri Hita Karana yang praktis. Penelitian ini merupakan penelitian pengembangan dengan model pengembangan ADDIE yang terdiri atas lima tahapan, yaitu Analyze (analisis), Design (rancangan), Development (pengembangan), Implementation (implementasi), dan Evaluation (evaluasi). Data dianalisis dengan menggunakan Content Validity Ratio (CVR) untuk validitas expert, Product Moment untuk validitas empirik, dan Mean untuk kepraktisan. Validitas diukur dengan menggunakan uji expert sebanyak lima orang yang terdiri dari tiga orang dosen expert dan dua orang guru sebagai praktisi. Hasil penelitian menunjukkan bahwa lembar kerja peserta didik IPA berorientasi Tri Hita Karana dikategorikan valid dengan nilai CVR 1 dan nilai CVI 1. Validitas empirik lembar kerja peserta didik IPA berorientasi Tri Hita Karana dinilai oleh sepuluh orang guru kelas V SD sebagai praktisi. Uji validitas empirik menunjukkan hasil valid melalui analisis korelasi product moment melalui bantuan SPSS versi 25 , nilai tiap butir pernyataan $r_{\text {hitung }} \geq r_{\text {tabel }}(0,632$ untuk signifikansi $5 \%)$. Hasil uji kepraktisan dinilai oleh enam puluh orang peserta didik kelas V SD. Hasil uji kepraktisan menunjukkan lembar kerja peserta didik IPA berorientasi Tri Hita Karana dikategorikan sangat praktis dengan nilai mean 169,57. Berdasarkan hasil tersebut, dapat disimpulkan bahwa penelitian ini menghasilkan lembar kerja peserta didik IPA berorientasi Tri Hita Karana yang valid dan praktis.
\end{abstract}

Kata Kunci : IPA; LKPD; Tri Hita Karana

\begin{abstract}
This research aims to obtain: 1) valid Tri Hita Karana oriented science student worksheets; 2) Practical Tri Hita Karana oriented science student worksheets. This research is a development research with the ADDIE development model which consists of five stages, namely Analyze (analysis), Design (design), Development (development), Implementation (implementation), and Evaluation (evaluation). Data were analyzed using Content Validity Ratio (CVR) for expert validity, Product Moment for empirical validity, and Mean for practicality. Validity was measured using an expert test of five people consisting of three expert lecturers and two teachers as practitioners. The results showed that the Tri Hita Karana-oriented science student worksheets were categorized as valid with a CVR value of 1 and a CVI value of 1 . The empirical validity of the Tri Hita Karana-oriented science student worksheets was assessed by ten fifth grade elementary school teachers as practitioners. The empirical validity test shows valid results through product moment correlation analysis through the help of SPSS version 25 , the value of each statement item is rcount rtable ( 0.632 for $5 \%$ significance). The results of the practicality test were assessed by sixty fifth grade elementary school students. The results of the practicality test show that the Tri Hita Karana oriented science student worksheets are categorized as very practical with a mean value of 169.57. Based on these results, it can be concluded that this study produced a valid and practical Tri Hita Karana oriented science student worksheet.
\end{abstract}

Keywords : Science; Student Worksheet; Tri Hita Karana 


\section{PENDAHULUAN}

Pendidikan dasar adalah pondasi fundamental kehidupan bangsa yang bermaksud memberikan bekal pengetahuan dan akhlak mulia kepada generasi untuk dapat menjadi SDM yang unggul dan bertanggungjawab. Taufiq (2014) mengungkapkan bahwa Pendidikan idealnya mempunyai tiga karakteristik, yaitu 1) pengembangan sikap dan pengetahuan tempatnya berada, 2) pengondisian pengaruh lingkungan, dan 3) pengembangan watak. Fungsi dan tujuan pendidikan nasional yang termuat pada Undang-Undang Nomor 20 Tahun 2003 tentang Sistem Pendidikan Nasional adalah pendidikan nasional pada intinya berfungsi untuk membentuk watak dan bertujuan untuk mewujudkan generasi yang memiliki kecerdasan, keterampilan, dan karakter yang mulia.

PP Nomor 28 Tahun 1990 tentang Pendidikan Dasar menyatakan bahwa tujuan pendidikan dasar pada intinya adalah memberikan bekal dasar untuk dapat melanjutkan pada jenjang selanjutnya. Hal ini berarti pendidikan dasar sebagai pondasi pendidikan memiliki peran vital dalam penentuan kualitas SDM. Pembelajaran di SD salah satunya mengenai muatan pelajaran IPA.

Pembelajaran IPA pada hakikatnya sebagai suatu produk, proses, sikap, dan teknologi. IPA sebagai bagian Pendidikan nasional hendaknya dilaksanakan secara saintifik guna dapat dapat mengembangkan kemampuan berpikir kitis dan ilmiah sebagai bekal keterampilan hidup (BSNP, 2006). Muatan pelajaran IPA di SD hendaknya dapat menjadi sarana menumbuhkan pemahaman terhadap diri dan lingkungan. Penekanan yang dilaksanakan sebaiknya bagaimana anak dapat merespon secara mandiri untuk perkembangan diri.

IPA di SD hendaknya memberikan ruang adanya upaya peserta didik untuk mencari tahu, sehingga terbangun konsepsi ilmiah. Awang (2015) dalam mengungkapkan ternyata penguasaan konsep IPA peserta didik masih kurang. Temuannya menunjukkan sulitnya mempelajari IPA di SD karena dua faktor yaitu faktor dari dalam dan faktor dari luar. Faktor dari dalam mencakup minat, semangat, kepercaya diri, rutinitas belajar, dan tujuan masa depan. Faktor dari luarnya antara lain banyak istilah yang tidak biasa, materi yang banyak, siswa terpaksa menghapal materi, terbatasnya media pembelajaran, teacher center, dan lemahnya penguasaan materi oleh guru.

LKPD berperan strategis guna mewujudkan pola belajar yang pusatnya ada pada peserta didik. Adanya LKPD dapat memberikan bantuan kepada guru untuk menfasilitasi peserta didik sekaligus peserta didik lebih mudah memeroleh pembelajaran yang bermakna. Hal senada diungkapkan oleh Setiawan, dkk (2019) perlu adanya inovasi dalam kegiatan belajar agar tidak semata mencatat, ceramah, dan mendengarkan pernjelasan. Pola yang monoton cenderung membuat peserta didik bosan sehingga proses pembelajaran tidak terlaksana optimal. LKPD sangat bermanfaat membantu guru untuk membuat suasana pembelajaran menjadi lebih komunikatif. Peserta didik didorong untuk dapat terjadinya konstruksi pengetahuan dan menstimulus rasa ingin tahu. Mengacu pada berbagai paparan tersebut, semestinya hasil belajar IPA di SD dapat tercapai optimal.

Faktanya, menurut OECD (2019) hasil penilaian dari Program for International Student Assessment (PISA) pada tahun 2018 yaitu penilaian tentang literasi, matematika, dan IPA. Peringkat Indonesia ada pada posisi 6 dari bawah dari 78 negara. Rata-rata skor membaca/literasi 371, skor matematika 379, skor IPA (sains) 396. Peserta didik yang terlibat pada pengukuran PISA yang dilaksanakan oleh OECD pada tahun 2018 
adalah 12.098 orang dari 399 sekolah di beberapa wilayah Indonesia. Data yang disampaikan OECD dapat dimaknai menjadi beberapa poin penting berikut 1) kemampuan baca siswa rendah, 2) skor matematika dan sains tidak mampu melewati batas rata-rata minimal, 3) alaman kecendrungan penurunan peringkat sejak tahun 2001 , 4) persentase capaian rendah yang menjadi pengingat agar di Indonesia terjadi perubahan paradigma pendidikan, dan 5) pemerataan mutu untuk mengantisipasi disparitas kualitas pendidikan. Fakta mengenai hasil tersebut juga sangat terkait dengan lemahnya keterampilan yang diasah melalui LKPD.

Hadi \& Novaliyosi (2019) mengungkapkan penilaian TIMSS terbaru sangat memprihatinkan yakni Indonesia ada pada posisi 44 dari 49 negara dengan rerata nilai 397 sedangkan rerata skor di dunia adalah 500. TIMSS membagi kriteria menjadi empat: nilai 400 (kriteria rendah), nilai 475 (kriteria sedang), nilai 550 (kriteria tinggi), dan nilai 625 (kriteria lanjut), dapat dicermati bahwa kondisi Indonesia berada pada tingkat rendah. Rerata nilai Matematika dan IPA di Indonesia pada pengukuran tersebut tergolong masih rendah. Siswa berpendapat bahwa muatan pelajaran IPA tidak mudah dipahami jika dikomparasi dengan pelajaran yang lain. Guru dalam menyampaikan pembelajaran masih menggunakan model ceramah, belum sepenuhnya mampu menggunakan model, strategi, dan media pembelajaran yang memadai (Anggreani, dkk, 2018). Potret ini membuat peserta didik menjadi jenuh dan tidak tertarik dengan pola pembelajaran yang statis akibat ketidakvariatifan strategi guru. Penjelasan konsep IPA jika tanpa bantuan media yang kreatif dan memadai maka mempersulit peserta didik dalam mengonstruksi pengetahuan. Penggunaan LKPD oleh guru cenderung hanya menggunakan LKPD yang sudah ada tanpa mengalami modifikasi. Hal ini sesuai dengan Danial \& Sanusi (2020) yang mengungkapkan guru semata menyodorkan LKPD baku yang berasal dari penerbit buku sehingga guru tidak memiliki ruang dalam berkreasi sesuai situasi pembelajaran setempat. Peserta didik tidak antusias dalam mengungkap potensi berpikir yang terpendam. Peserta didik hanya diajak untuk menjawab soal dan diberikan PR.

Berdasarkan hasil wawancara pada 4 Maret 2021 dengan salah satu guru di SD Negeri 2 Besakih menunjukkan bahwa guru tidak terbiasa mengaplikasikan bahan ajar yang terbarukan, bahan ajar hanya mengacu dengan apa yang sudah tertuang dalam buku paket. Metode yang digunakan oleh guru cenderung monoton dengan cara ceramah yang menyebabkan peserta didik bosan kemudian tidak konsentrasi. Peserta didik yang tidak konsentrasi cenderung mengalihkan perhatian untuk mengerjakan hal di luar pelajaran sehingga kondisi kelas menjadi riuh dan tidak kondusif. Guru jarang membuka ruang diskusi sehingga peserta didik tidak berkesempatan untuk mendapatkan informasi dari sumber lain yang terkait, pengetahuan peserta didik juga tidak terkonstruksi secara optimal. Adanya bahan ajar yang menampilkan berbagai gambar, animasi, dan warnawarni akan menciptakan atmosfer baru sehingga peserta didik lebih antusias dalam belajar di sekolah.

Lebih lanjut diungkapkan bahwa bentuk/tampilan disain LKPD yang digunakan cenderung tidak menarik, hanya berwarna pada bagian sampul dan menggunakan kertas buram pada bagian isi. LKPD hanya memuat ringkasan soal dan menjawab berbagai soal (pilihan ganda dan esai). Hal ini mengakibatkan peserta didik menjadi bosan dan malas. Apalagi biasanya guru cenderung menggunakan LKPD hanya untuk bahan pekerjaan rumah (PR) sehingga peserta didik mengganggap seolah-olah kegiatan belajar hanya sebatas mengerjakan latihan soal pada LKPD. Dampaknya, 
peserta didik di rumah tidak berupaya mandiri dalam menghadapi persoalan tetapi menggunakan cara yang instan dalam menjawab soal seperti meniru pekerjaan orang lain, dibantu orang tua, guru bimbel, dan orang lain untuk menyelesaikannya. Jika fenomena ini tidak diatasai maka akan tumbuh karakter yang buruk seperti malas, mudah menyerah, cepat puas, dan sebagainya. Peserta didik akan memiliki pemikiran yang instan tanpa memikirkan prosesnya.

Permasalahan hasil belajar IPA yang rendah berdampak semakin meluas dan berpotensi adanya penurunan kualitas karakter peserta didik. Upaya yang dapat dilaksanakan dengann mengupayakan adanya perangkat pendukung pembelajaran yang inovatif. Perangkat pembelajaran yang erat penggunaannya dengan peserta didik adalah LKPD. Adanya dampak negatif yang mengarah pada kemrosotan kualitas karakter dapat diatasi dengan penerapan pola-pola Tri Hita Karana. Menurut Budiasih (2017) Tri Hita Karana memberikan sumbangsih dalam upaya proses character building pada peserta didik dengan harapan dapat menjadi cerdas, berkakhlak mulia, religious, dan memiliki kepedulian terhadap sesama dan lingkungan sekitar. Hal senada juga diungkapkan oleh Jaya (2019) bahwa pemusatan aplikasi filosofi Tri Hita Karana guna menciptakan karakter yang unggul dipandang tepat jika dimotori oleh lembaga pendidikan formal.

Berdasarkan paparan tersebut maka dipandang sangat mendesak adanya pengembangan LKPD berorientasi Tri Hita Karana. LKPD berorientasi Tri Hita Karana didefinisikan sebagai pengembangan bahan ajar yang lebih mementingkan aktivitas agar peserta didik proaktif dan mengaitkan pembelajaran dengan contoh nyata dalam keseharian. Contoh nyata dikaitkan dengan hubungan harmonis Tuhan, sesame manusia, dan alam linkungan sehingga suasana pembelajaran menjadi menyenangkan. Kelebihan Tri Hita Karana jika dimasukkan ke dalam LKPD adalah dapat meningkatkan partisipasi dan menguatkan karakter peserta didik.

Berdasarkan paparan yang disampaikan, perlu adanya berbagai usaha untuk memperbaiki kualitas pembelajaran dengan mengedepankan berbagai langkah kreatif dan inovatif. Upaya yang dapat dilaksanakan adalah mengembangkan bahan ajar peserta didik berupa LKPD berorientasi Tri Hita Karana. Aktivitas pembelajaran berorientasi Tri Hita Karana secara simultan diharapkan dapat menguatkan karakter peserta didik dan adanya peningkatan hasil belajar IPA. Maka dari itu, perlu dilaksanakan penelitian yang berjudul "Pengembangan Lembar Kerja Peserta Didik (LKPD) IPA Berorientasi Tri Hita Karana pada Kelas V Sekolah Dasar".

\section{METODE}

Penelitian ini adalah penelitian pengembangan yang diistilahkan juga dengan R \& D. Sugiyono (2009) mengungkapkan bahwa penelitian pengembangan merupakan aktivitas dasar guna memeroleh informasi keperluan pengguna, berlanjut pada aktivitas pengembangan guna memeroleh hasil dan kajian. Pertama melaksanakan aktivitas untuk mempelajari berbagai sumber literasi guna memeroleh draft produk. Kedua melaksanakan kegiatan pengujian validitas, kepraktisan, dan keefektivan suatu produk sehingga dapat bermanfaat bagi masyarakat luas yang membutuhkan.

Penelitian yang dilaksanakan berupaya untuk menciptakan Lembar Kerja Peserta Didik (LKPD) IPA berorientasi Tri Hita Karana. Model yang digunakan dalam penelitian ini adalah ADDIE (Analyze, Design, Development, Implementation, Evaluation). Adapun tahapan penelitian pengembangan ini mencakup 1) Analyze berupa analisis muatan KD pengetahuan dan keterampilan pada muatan pelajaran IPA tema 5 kelas V SD. 2) Design berupa 
rancangan aktivitas berorientasi Tri Hita Karana sesuai dengan muatan KD pengetahuan dan keterampilan tema 5 kelas V SD. 3) Development mencakup aktivitas pengembangan LKPD berorientasi Tri Hita Karana dan validasi oleh ahli. 4) Implementation mencakup kepraktisan LKPD berorientasi Tri Hita Karana pada tema 5 kelas V SD. 5) Evaluation berupa aktivitas mengevaluasi LKPD berorientasi Tri Hita Karana tema 5 kelas V SD.

Subjek penelitian merupakan sesuatu yang vital dalam penelitian karena erat hubungannya dengan data variabel yang diamati. Subjek penelitian ini merupakan orang yang terlibat dalam pengembangan produk berupa lembar kerja peserta didik IPA berorientasi Tri Hita Karana pada tema 5 kelas V SD. Subjek pada penelitian ini didasarkan pada validasi expert yang terdiri dari lima orang. Expert yang dimaksud terdiri atas tiga orang dosen Program Pascasarjana S2 Pendidikan Dasar Undiksha dan dua orang praktisi guru sekolah dasar yang berpengalaman mengajar di atas lima tahun. Expert akan menilai kisi-kisi, instrumen validasi ahli, dan produk yang dikembangkan.

Langkah prosedur yang ditempuh sesuai dengan tahapan ADDIE. Tahap Analyze (analisis) mencakup analisis kebutuhan guru, kebutuhan peserta didik, dan kurikulum. Analisis kebutuhan guru dan peserta didik diketahui melalui pemberian angket/kuesioner. Analisis kurikulum dilaksanakan dengan menganalisis $\mathrm{KI}, \mathrm{KD}$, dan indikator yang terdapat pada buku siswa kelas V SD sehingga dapat ditentukan materi pada tema yang akan dikembangkan. Tahap Design mencakup penyusunan LKPD IPA berorientasi Tri Hita Karana yang menghasilkan draft I, pada tahapan ini juga disusun instrumen validasi dan angket kepraktisian. Keseluruhan berkas diperiksa oleh pembimbing sehingga menghasilkan revisi I berupa draft II. Tahap Development mencakup proses validasi expert sehingga menghasilkan revisi II berupa draft III. Saat validasi expert produk dan instrumen dapat berubah sesuai dengan ketentuan dan kebutuhan penelitian. Saat proses development ini pula dilaksanakan validasi empirik dan uji kepraktisan. Tahapan selanjutnya adalah implementation dan evaluation. Dua tahapan terakhir tidak dapat dilaksanakan karena berbagai kendala dalam situasi pandemi Corona Virus Diseases-19 (Covid-19).

Variabel pada penelitian ini adalah LKPD IPA berorientasi Tri Hita Karana yang valid dan LKPD IPA berorientasi Tri Hita Karana yang praktis. LKPD IPA berorientasi Tri Hita Karana yang valid adalah LKPD yang memenuhi aturan LKPD, yaitu terdiri dari syarat didaktik, konstruksi, dan teknis. Syarat didaktik adalah mengacu pada ketentuan belajar sesuai standar. Syarat konstruktif berkaitan dengan penggunaan bahasa dan kalimat. Syarat teknis adalah yang berkaitan dengan visual/tampilan. LKPD dinyatakan valid apabila memperoleh hasil penilaian yang sesuai dengan kriteria validitas expert dan validitas empirik. LKPD IPA berorientasi Tri Hita Karana yang praktis adalah LKPD yang mudah dan menyenangkan saat diaplikasikan oleh pengguna. Pengguna LKPD dalam hal ini adalah peserta didik. LKPD dinyatakan praktis ketika nilai rerata $(\mathrm{M})$ memenuhi kriteria pada Penilaian Acuan Ideal Teoritik (PAIT). LKPD yang praktis diperoleh melalui hasil pengisian angket kepraktisan yang dinilai peserta didik. Pengisian angket kepraktisan oleh 60 peserta didik sebagai pengguna.

Pengumpulan data menggunakan metode angket. Pengumpulan data melalui angket berupa penilaian validasi dan kepraktisan. Angket validasi diisi oleh 3 orang dosen sebagai ahli dan 2 orang guru SD sebagai praktisi. Angket kepraktisan diisi oleh 60 orang siswa SD kelas $\mathrm{V}$. Instrumen yang digunakan pada penelitian ini adalah lembar validasi dan lembar angket. Lembar validasi yang 
dipakai pada penelitian ini adalah validasi kelayakan produk. Tahap uji validitas dilaksanakan setelah rampungnya pembuatan produk dan telah siap diuji. Validasi melibatkan 3 orang dosen sebagai ahli dan 2 orang guru SD sebagai praktisi. Validator ditentukan berdasarkan pengalaman dalam merancang, mengimplementasikan, dan menilai pembelajaran IPA yang diakui sebagai pendidik. Dosen yang melaksanakan proses validasi adalah dosen S2 Program Pascasarjana, Prodi Pendidikan Dasar Undiksha. Guru yang melaksanakan proses validasi adalah guru kelas $\mathrm{V}$ SD yang memiliki lima tahun pengalaman mengajar. Lembar angket adalah kumpulan pernyataan atau pertanyaan yang diberikan kepada subjek penelitian (Arikunto, 2017). Angket kepraktisan ini diberikan kepada 60 peserta didik kelas $\mathrm{V}$ SD sebagai pengguna.

Data akan dianalisis secara deskriptif yang berasal dari analisis kebutuhan, karakteristik produk, uji validitas dan kepraktisan. Uji validitas mencakup data dari expert judges dan praktisi sebagai pengguna. Uji kepraktisan mencakup data yang diperoleh melalui pengisian angket oleh peserta didik. Validasi expert yang diperoleh dari ahli dan praktisi akan menghasilkan data yang selanjutnya akan diuji validitasnya. Data uji validitas dari ahli dan praktisi diisi melalui skala likert terhadap LKPD berorientasi Tri Hita Karana serta masukan lainnya. Validasi dilakukan oleh ahli dan praktisi bertujuan untuk memastikan produk yang dikembangkan sudah sesuai dengan prosedur yang berlaku. Uji validitas isi dilaksanakan melalui perhitungan Content Validity Ratio (CVR). Lawshe (1975) mengungkapkan bahwa CVR adalah sebuah analisis isi yang bertujuan untuk mengetahui kesesuaian produk yang dikembangkan berdasarkan penilaian para ahli. Ahli yang terlibat dalam validitas isi ini antara lain: tiga orang expert dalam bidang pendidikan dan dua orang praktisi guru kelas $V$ SD.
Adapun rumus yang digunakan oleh Lawshe untuk mengukur atau menghitung nilai CVR adalah sebagai berikut.

$$
C V R=\frac{n_{e}-\frac{N}{2}}{\frac{N}{2}}
$$

(Lawshe, 1975)

Keterangan:

$$
\begin{array}{ll}
C V R= & \text { rasio validitas isi } \\
n & =\text { jumlah ahli atau judgement } \\
& \text { pemberi nilai } \\
& \text { (penting/relevan/esensial) } \\
N & =\text { jumlah ahli atau judgement }
\end{array}
$$

Butir yang valid akan dihitung lebih lanjut dengan menggunakan indeks validitas konten (CVI), yang rumusnya adalah sebagai berikut:

$$
C V I=\frac{\sum C V R}{\text { Jumlah Soal }}
$$

Validitas empiris sebagai nilai guna menunjukkan kecermatan instrument dalam melaksanakan pengukuran berdasarkan fakta empiris atau pengalamannya. Valititas yang tinggi menyatakan instrument tersebut valid. Validitas empiris ini menggunakan bantuan perhitungan korelasi product moment. Menurut Sugiyono (2019) dinyatakan sebagai berikut:

$$
\begin{aligned}
& \boldsymbol{r}_{\boldsymbol{x} y} \\
& =\frac{\boldsymbol{N} \sum X \boldsymbol{Y}-\left(\sum X\right)\left(\sum \boldsymbol{Y}\right)}{\sqrt{\left\{N \sum X^{2}-\left(\sum X\right)^{2}\right\}\left\{N \sum \boldsymbol{Y}^{2}-\left(\sum \boldsymbol{Y}\right)^{2}\right\}}}
\end{aligned}
$$

Keterangan:

$$
\begin{array}{lll}
\boldsymbol{r}_{x y} & = & \text { Koefisien korelasi yang } \\
& & \text { menyatakan validitas } \\
X & = & \text { Skor butir soal } \\
Y & = & \text { Skor total } \\
N & = & \text { Jumlah sampel }
\end{array}
$$


Kepraktisan produk dilakukan melalui pengisian angket oleh pengguna yaitu peserta didik. Peserta didik mengisi angket kepraktisan LKPD beorientasi Tri Hita Karana. Adapun data dari uji kepraktisan ini disajikan dalam lima kategori yaitu sangat praktis, praktis, cukup praktis, kurang praktis dan sangat kurang praktis. Data mengenai kepraktisan produk yang dikembangkan diperoleh dari angket respon peserta didik. Data yang didapatkan selanjutnya dianalisis untuk mengamati nilai kepraktisan produk yang dikembangkan. Skor rata-rata masing-masing responden dihitung kemudian dirata-ratakan sampai diperoleh skor total, melalui rumus berikut.

$$
\mathrm{M}=\frac{\sum f X}{N}
$$

(Agung, 2014)

Keterangan:

$$
\begin{array}{ll}
\mathrm{M} & =\text { nilai rerata } \\
\sum_{N} f X & =\text { jumlah nilai seluruh responden } \\
& =\text { banyaknya responden }
\end{array}
$$

\section{HASIL DAN PEMBAHASAN}

Hasil penelitian ini meliputi deskripsi Lembar Kerja Peserta Didik (LKPD) IPA berorientasi Tri Hita Karana, validasi produk, dan kepraktisan produk. Hasil dari validasi produk adalah penilaian dan masukan dari ahli dan praktisi. Penilaian kepraktisan merupakan hasil respon dari peserta didik. Tahapan analyze, pada analisis kebutuhan mengungkapkan fakta bahwa pada intinya seluruh responden beranggapan penting adanya pengembangan/inovasi LKPD untuk mengaitkan dengan kehidupan sehari-hari, pembelajaran lebih bermakna, dan untuk membuat pembelajaran IPA lebih menarik. Berdasarkan analisis kompetensi dasar yang dilaksanakan dipilih kompetensi pengetahuan IPA 3.5 Menganalisis hubungan antara komponen ekosistem dan jaring-jaring makanan di lingkungan sekitar dan kompetensi keterampilan IPA 4.5 Membuat karya tentang konsep jaring- jaring makanan dalam suatu ekosistem. Kompetensi dasar pengetahuan dan keterampilan ini termuat dalam Tema V Ekosistem kelas V SD.

Tahapan design, pada tahapan design peneliti mulai menyusun produk yang akan dikembangkan. Produk yang dikembangkan adalah LKPD IPA berorientasi Tri Hita Karana. Rangkaian langkah yang dilaksanakan adalah pengembangan LKPD IPA berorientasi Tri Hita Karana, penyusunan kisi-kisi validasi dan kepraktisan, serta penyusunan instrumen instrumen validasi dan kepraktisan. Tahapan design ini menghasilkan draft LKPD IPA berorientasi Tri Hita Karana. Draft mencakup rangkaian kegiatan, disain cover dan disain layout yang memenuhi aspek-aspek LKPD yang baik melalui syarat didaktik, konstruktif, dan teknis. Tahap design juga menghasilkan instrumen untuk mengukur validitas dan kepraktisan LKPD yang dikembangkan.

tahap inti $\begin{array}{rr}\text { Tahapan } & \text { development } \\ \text { dalam } & \text { penelitian }\end{array}$ pengembangan. Langkah pada tahap ini adalah menelaah kuesioner/angket dan produk LKPD IPA berorientasi Tri Hita Krana dengan cara memilih lima orang judges pendidikan untuk menilai dan memberikan saran konstruktif terhadap produk pengembangan. Judges berasal dari tiga orang dosen ahli S2 Pascasarjana Program Studi Pendidikan Dasar Undiksha dan dua orang guru sebagai praktisi. Syarat guru sebagai praktisi yang dijadikan judges adalah memiliki pengalaman mengajar minimal lima tahun. Selain memberikan penilaian pada lembar validasi, judges juga diperkenankan untuk memberikan saran/masukan secara tertulis dalam upaya perbaikan kualitas LKPD yang dikembangkan. Saran/masukan dari judges dijadikan acuan untuk merevisi pengembangan produk sehingga dapat mencapai kualitas yang semakin baik. Pengembangan LKPD mengikuti ketentuan yang mencakup aspek didaktik, 
konstruktif, dan teknis. Secara operasional, tahap pengembangan LKPD meliputi rangkaian aktivitas peserta didik untuk mencapai $\mathrm{KI}-\mathrm{KD}$, orientasi Tri Hita Karana, pemilihan ilustrasi yang sesuai, pengembangan disain cover dan layout, tata letak, pemilihan font, dan pengaturan keserasian/harmonisasi disain dan tulisan.

Berdasarkan hasil penilaian dari judges Lembar Kerja Peserta Didik (LKPD) IPA berorientasi Tri Hita Karana dikategorikan valid. Lawshe (1975) mengungkapkan bahwa nilai minimun CVR untuk $\boldsymbol{\alpha}=0,05$ dengan responden lima orang adalah 0,99 . Berdasarkan 30 butir pernyataan pada instrumen validasi, seluruhnya mendapatkan nilai 1 yang memenuhi syarat nilai minimum CVR sehingga seluruh item penilaian validasi produk LKPD IPA berorientasi Tri Hita Karana terpenuhi. Hal ini berarti produk yang dikembangkan valid. Perhitungan pada CVR dilanjutkan dengan mencari nilai indeks validitas konten (CVI). Sederhananya $\mathrm{CVI}$ adalah reata dari nilai CVR. Lembar Kerja Peserta Didik (LKPD) IPA berorientasi Tri Hita Karana memperoleh nilai 1 pada CVI sehingga masuk dalam kriteria sangat valid. Hal ini didasarkan pada kategori hasil perhitungan $\mathrm{CVI}$ dengan rentang nilai 0,68 - 1,00 masuk kategori sangat valid.

Validitas empirik didapatkan melalui perhitungan korelasi product moment. Perhitungan validitas empirik dilaksanakan dengan mengolah hasil yang diinput oleh 10 orang guru sebagai praktisi pendidikan yang mengajar di lingkup satu kecamatan. Jika $r_{\text {hitung }}$ lebih besar daripada $r_{\text {tabel }}$ (pada taraf signifikansi 5\%) maka butir pernyataan dinyatakan valid, diperoleh hasil untuk semua butir $r_{\text {hitung }} \geq r_{\text {tabel }}(0,632)$ sehingga produk dinyatakan valid. Uji kepraktisan dilaksanakan dengan mengolah data angket kepraktisan yang diisi oleh 60 orang peserta didik sebagai pengguna. Pernyataan pada angket kepraktisan berjumlah 35 butir. Angket ini sudah melalui tahapan judges dari dua orang dosen S2 Pascasarjana, Program
Studi Pendidikan Dasar Undiksha untuk memastikan angket ini layak dan tepat digunakan untuk mengukur kepraktisan produk. Validasi angket menggunakan analisis Gregory, hasil judges menunjukkan bahwa seluruh butir pernyataan valid untuk digunakan. Perhitungan uji kepraktisann produk yang dikembangkan menggunakan rumus mean (nilai rerata) dengan membagi seluruh jumlah nilai responden dengan banyaknya responden.

Perhitungan menghasilkan nilai rerata (M) 169,57. Hasil nilai rerata (M) dikonversikan menjadi nilai kualitatif dengan menggunakan kategori/kriteria Penilaian Acuan Ideal Teoritik (PAIT). Nilai perhitungan yang diperoleh termasuk dalam kriteria sangat praktis $(\mathrm{Mi}+1.5 \mathrm{sdi}$ $\leq \mathrm{x} \leq \mathrm{mi}+3.0 \mathrm{sdi}$ ). LKPD IPA berorientasi Tri Hita Karana pada kriteria sangat praktis artinya LKPD ini mudah digunakan.

Analisis data pada validasi expert didasarkan atas enam aspek yaitu aspek didaktik, konstruktif, teknis, Parhyangan, Pawongan, dan Palemahan. Hasil validitas expert diperoleh $\mathrm{CVR}=1$ dan $\mathrm{CVI}=1$ sehingga LKPD dinyatakan valid secara expert. Aspek didaktik adalah aspek yang menekankan pada pola belajar yang efektif dan efisien. Depdiknas (2008) mengungkapkan bahwa bahan ajar (LKPD) yang dikembangkan agar mengacu pada ketentuan kurikulum. Aspek konstruktif berkenaan dengan penggunaan bahasa, susunan kalimat, kosakata, dan tingkat kesukaran. Menurut Depdiknas (2008) LKPD (bahan ajar) wajib memuat kalimat yang jelas dan kalimat tidak terlalu panjang. Aspek teknis mencakup tulisan, gambar, dan penampilan. Depdiknas (2008) mengungkapkan bahwa komponen sajian meliputi kejelasan tujuan yang ingin dicapai, urutan sajian, daya tarik, dan informasi yang lengkap. Lebih lanjut disampaikan bahwa huruf yang digunakan dalam bahan ajar cetak tidak boleh terlalu kecil dan wajib mudah dibaca. Pemilihan warna latar agar kontras dengan huruf 
sehingga tulisan mudah dibaca. Bagian tertentu digunakan tulisan dengan warna dan ukuran yang berbeda sehingga peserta didik lebih menarik untuk membacanya. Hasil analisis data menunjukkan bahwa seluruh aspek validitas terpenuhi termasuk aspek yang memuat orientasi Tri Hita Karana. Pembelajaran berorientasi Tri Hita Karana dapat mengarahkan peserta didik untuk mampu memahami konsep dan meningkatkan sikap postif baik dalam spiritual dan sosial.

LKPD yang praktis artinya mudah dan menyenangkan untuk digunakan. Uji kepraktisan melibatkan enam puluh orang peserta didik kelas V SD. Mengacu pada Penilaian Acuan Ideal Teoritik (PAIT) nilai mean observasi diperoleh 169,57 sehingga termasuk dalam kriteria sangat praktis. Bahasan kepraktisan memuat tiga komponen utama yaitu 1) petunjuk, bahasa, dan tampilan, 2) penggunaan dan aktivitas pembelajaran, dan 3) orientasi Tri Hita Karana. Menurut BSNP (2013) bahwa standar bahasa, keterbacaan dalam bahan ajar mencnakup kejelasan bahasa yang digunakan, bahasa yang baik dan benar, serta kejelasan untuk dibaca. Sumiati dan Asra (2007) mengungkapkan bahwa LKPD dapat memberikan bantuan kepada peserta didik untuk memproses hasil belajar berupa penemuan dan pembuktian konsep pada pembelajaran yang telah dilalui. Hal lainnya disampaikan oleh Sukardi (2008) bahwa secara praktis wajib mempertimbangkan waktu dan prosedur penggunaan agar singkat, cepat, dan tepat. Terkait sisi penggunaan, Majid (2011) mengungkapkan bahwa LKPD dapat memberikan bantuan kepada peserta didik untuk lebih mudah memahami pelajaran serta membantu guru dalam persiapan proses belajar mengajar.

Orientasi Tri Hita Karana pada LKPD IPA ini membuat pembelajaran semakin menyenangkan dan bermakna. Konsep Tri Hita Karana juga erat kaitannya dengan penguatan pendidikan karakter. Budiasih
(2017) pendidikan karakter yang diproses melalui konsep Tri Hita Karana mencakup beberapa hal berikut 1) pengetahuan (knowledge) artinya pembelajaran menjadi media bagi peserta didik untuk mengalami hal-hal yang bermakna. 2) Keterampilan (skill) artinya pembelajaran agar sungguhsungguh memberikan keterampilan peserta didik (kognitif, afektif, dan psikomotorik). 3) Sifat alamiah (dispositions), artinya pembelajaran agar secara sungguh dijalankan tanpa ada paksaan, alamiah, dan bukan hanya rutinitas. 4) Perasaan (feeling) artinya perasaan ini bermakna hal-hal yang berhubungan dengan kepekaan dan rasa.

Pemaknaan Tri Hita Karana secara garis besar adalah sebagai berikut, keharmonisan antara manusia dengan Tuhan menghadirkan ketakwaan dan rasa syukur yang menciptkan ketentraman hati. Suasana tentram berimplikasi pada situasi pembelajaran yang kondusif sehingga proses pembelajaran semakin optimal. Keharmonisan antara anusia dengan manusia akan menumbuhkan interaksi kemanusiaan yang humanis, semangat gotong royong, serta kolaborasi tolong menolong. Hal ini akan menghadirkan kenyamanan. Rasa nyaman dalam belajar akan mendukung proses konstruksi pengetahuan. Keharmonisan antara manusia dengan lingkungan akan membentuk lingkungan hidup yang harmoni sehingga terjadi lingkungan yang lestari. Adanya lingkungan yang lestari akan kembali memberikan rasa nyaman dan kondusivitas dalam aktivitas belajar. Keseimbangan, keharmonisan, dan kebahagiaan akan tercapai apabila manusia menjaga keharmonisan hubungan secara vertikal kepada Tuhan, secara horizontal kepada sesaa manusia dan lingkungan. Jika dihubungkan dengan dengan filsafat progresif dan humanistik dalam pendidikan, pendidikan berupaya untuk memanusiakan manusia yang secara bertahap akan menghasilkan manusia yang unggul berkarakter. Hal ini sebagai cerminan bahwa konsep Tri Hita Karana memang sangat relevan sebagai basis pendidikan. 


\section{PENUTUP}

Berdasarkan hasil penelitian dan pembahasan penelitian pengembangan LKPD IPA berorientasi Tri Hita Karana pada Kelas $\vee$ SD, dapat ditarik kesimpulan sebagai berikut. 1) LKPD IPA berorientasi Tri Hita Karana pada kelas V SD valid secara expert dengan nilai $C V R=1$ dan $\mathrm{CVI}=1$ serta valid secara empirik dengan nilai $r_{x y}>0,632$. 2) LKPD IPA berorientasi Tri Hita Karana pada kelas V SD ini ada pada kategori "sangat praktis" dengan nilai rerata (mean) yang diperoleh adalah 169,57. Adapun berbagai saran dapat disampaikan sebagai berikut.

1. Bagi Pemerintah, hendaknya agar meningkatkan frekeunsi kegiatan pelatihan, workshop, dan sejenisnya yang bertujuan untuk melatih kemampuan guru dalam upaya mengembangkan berbagai bahan ajar inovatif khususnya berupa LKPD.

2. Bagi Kepala Sekolah Dasar, hendaknya agar memfasilitasi dan memperluas ruang gerak guru dalam upaya mengembangkan berbagai kreativitas khususnya dalam pengembangan dan/atau modifikasi LKPD yang inovatif dan bermakna.

3. Bagi Guru Sekolah Dasar, hendaknya agar lebih mengoptimalkan potensi diri dalam upaya mengembangkan dan/atau menyesuaikan LKPD dengan lingkungan sekolah dan karakteristik peserta didik sehingga terbangun suasana yang kondusif dan pembelajaran semakin bermakna.

4. Bagi peneliti selanjutnya diharapkan agar dapat mengadakan penelitian mengenai pengaruh LKPD IPA berorientasi Tri Hita Karana pada Kelas V SD terhadap penguatan karakter dan stimulus keterampilan abad ke-21 yang dialami oleh peserta didik.

\section{DAFTAR RUJUKAN}

Awang, Imanuel Sairo. 2015. "Kesulitan Belajar IPA Peserta Didik Sekolah Dasar". Jurnal Vox Edukasi, Volume 6, Nomor 2, 2015, hlm. 108-122. Tersedia pada http://jurnal. Stkipper sada.ac.id/jurnal/index.php/VOX/arti cle/view/106 (diakses tanggal 5 Maret 2021).

Anggreani, Asteria Lindiyana, Choirul Huda, dan Eka Sari Setianingsih. 2018. "Pengaruh Strategi Card Sort Berbantu Media Gambar terhadap Prestasi Belajar IPA". Jurnal IImiah Sekolah Dasar, Volume 2, Nomor 4, 2018, hlm. 365-370. Tersedia pada https://ejournal.undiksha.ac.id/index. php/JISD/article/view/16153 (diakses tanggal 2 Februari 2021).

Arikunto, $\quad$ Suharsimi. 2017. Pengembangan Instrumen Penelitian dan Penilaian Program. Yogyakarta: Pustaka Pelajar.

BSNP. 2006. Standar Isi. Jakarta: Depdiknas.

BSNP. 2013. "Kegiatan Penilaian Buku Teks Pelajaran Pendidikan Dasar dan Menengah". Jakarta: Departemen Pendidikan Nasional.

Budiasih, Ni Wayan. 2017. "Implementasi Pendidikan Karakter Anak Sekolah Dasar melalui Ajaran Tri Hita Karana". Adi Widya: Jurnal Pendidikan Dasar, Volume 1, Nomor 1, 2017, hlm. 56-64. Tersedia pada https://ejournal.ihdn. ac.id/index.php/ AW/article/view/955 (diakses tanggal 30 April 2021).

Danial, Muhammad \& Sanusi, Wahidah. 2020. "Penyusunan Lembar Kegiatan Peserta Didik (LKPD) berbasis Investigasi bagi Guru Sekolah Dasar Negeri Parangtambung II Kota Makasar". Prosiding Seminar Nasional, Makasar: Lembaga Penelitian dan Pengabdian kepada Masyarakat Universitas Negeri Makasar. Tersedia pada https://ojs. unm.ac.id/semnaslpm/article/view/11 888/7003 (diakses tanggal 7 Februari 2021).

Depdiknas. 2008. "Panduan Pengembangan Bahan Ajar". Jakarta: 
Departemen Penddikan Nasional Direktorat Jenderal Manajemen Pendidikan Dasar dan Menengah.

Hadi, Syamsul \& Novaliyosi. 2019. "TIMSS Indonesia (Trends in International Mathematics and Science Study)". Prosiding Seminar Nasional \& Call for Papers, Tasikmalaya: Program Studi Magister Pendidikan Matematika Universitas Siliwangi. Tersedia pada http://jurnal.unsil.ac.id/index.php/snc $\mathrm{p} /$ article/viewFile/1096/754 (diakses tanggal 12 Februari 2021).

Jaya, Kadek Arta. 2019. "Membangun Mutu Pendidikan Karakter Siswa melalui Implementasi Ajaran Tri Hita Karana". Jurnal Penjaminan Mutu Lembaga Penjaminan Mutu Institut Hindu Dharma Negeri Denpasar, Volume 5, Nomor 1, 2019, hlm 57$67 . \quad$ Tersedia pada http://ejournal.indn. ac.id/index. php/JPM/article/view/759 (diakses tanggal 5 April 2021).

Majid, Abdul. 2011. "Perencanaan Pembelajaran”. Bandung: Remaja Rosdakarya.

OECD, 2019. PISA 2018 Results Combined Executive Summaries Volume I, II, \& III.

Peraturan Pemerintah Nomor 28 Tahun 1990 tentang Pendidikan Dasar. 1990. Jakarta: Pemerintah RI.

Priantini, Dewa Ayu Made Manu Okta \& Darwati, G. A. Mas. "Pengembangan Perangkat Pembelajaran Tematik Terpadu Berbasis Tri Hita Karana untuk Anak Sekolah Dasar". Makalah. Disampaikan pada Seminar Nasional INOVALI 2019. Tersedia pada https://eproceeding. undwi.ac.id/index.php/inobali/article/ view/93 (diakses tanggal 1 Mei 2021)

Putra, I Wayan Weda Gustana, Desak Putu Parmiti, I Wayan Ignatius
Suwatra. 2016. "Pengaruh Model Pembelajaran SAVI Bermuatan TriHita Karana terhadap Hasil Belajar IPA Siswa Kelas IV". EJournal Mimbar PGSD Universitas Pendidikan Ganesha, Volume 4, Nomor 1, 2016, hlm. 1-9. Tersedia pada https://garuda.ristekbrin.go.id/ documents/detail/1384583 (diakses tanggal 14 Februari 2021)

Setiawan, Ribud, Happy Susanto, dan Ayok Ariyanto. 2019. "Meningkatkan Prestasi Belajar Peserta Didik dengan Menggunakan Model Pembelajaran Snowball Throwing pada Mata Pelajaran IPA Energi Bunyi Kelas IV SDN II Pule Tahun Ajaran 2017/2018". Jurnal Mahasiswa Tarbawi, Volume 3, Nomor 1, 2019, hlm. 39-46. Tersedia pada http://studentjournal.umpo.ac. id/index.php/tarbawi/article/view/210 (diakses tanggal 23 Februari 2021).

Sudira, Putu. 2012. "Pendidikan Teknologi dan Kejuruan Spirit Tri Hita Karana". Makalah. Naskah Artikel Buku Pendidikan Teknologi dan Kejuruan Spirit THK. Tersedia pada https://www.researchgate.net/public ation/328457124_ SMK_kearifan_ lokal_Tri_Hita_Karana_THK (diakses tanggal 28 April 2021).

Sudira, Putu. 2014. "Perguruan Tinggi Unggul Berbasis Tri Hita Karana". Makalah. Disampaikan pada Dies Natalis VIII Universitas Pendidikan Ganesha, 7 Mei 2014 di Singaraja. Tersedia pada http://staffnew. uny.ac.id/upload/13165 5274/peneli tian/072-paper-undiksha-putu sudira-2014.pdf (diakses tanggal 18 Februari 2021).

Sugiyono. 2009. "Metode Penelitian Kuantitatif, Kualitatif, dan R\&D”. Bandung: Alfabeta CV.

Sukardi. 2012. "Evaluasi Pendidikan Prinsip dan Operasionalnya". Jakarta: PT Bumi Aksara. 
Vol. 5 No 2, Agustus 2021

ISSN: 2613-9553

Sumiati dan Asra. 2007. "Metode Pembelajaran". Bandung: CV. Wacana Prima.

Taufiq, Agus. 2014. Hakikat Pendidikan di Sekolah Dasar. Jakarta: Universitas Terbuka.

Undang-Undang Nomor 20 Tahun 2003 tentang Sistem Pendidikan Nasional. 